\title{
PENETAPAN ‘ADAM WALI NIKAH OLEH PEJABAT KUA DI KOTA SEMARANG
}

\author{
Rokhmadi \\ Universitas Islam Negeri (UIN) Walisongo, Semarang \\ e-mail:rokhmadi66@yahoo.com
}

\begin{abstract}
This article is result of the study that describes the determination concept of adam wali nikah by officials of the Religious Affairs Office (KUA) in Semarang, on marriage guardian of an ineligible woman, that because of the bride's birth is less than six months from her parents' marriage. Having determined adam marriage guardians' status, then KUA establishes that the marriage guardian is delegated to KUA officials in each region of Semarang. As for the basis used by those who determine the delegation for the reason of deficient condition of marriage guardians for a female to the KUA is the use of the legal basis contained in adam marriage guardians' determination in the letter of Director General Guidance and Pilgrimage Affairs Number: D/ED/PW.01/03/1992, in which its position is under the Marriage Legislation No. 1 of 1974 and the Islamic Law Compilation (KHI).
\end{abstract}

Tulisan ini merupakan hasil kajian yang mendeskripsikan penetapan konsep 'adam wali nikah oleh pejabat Kantor Urusan Agama (KUA) di Kota Semarang terhadap wali nikah seorang perempuan yang tidak memenuhi syarat, yakni karena kelahiran calon mempelai perempuan kurang dari enam bulan setelah perkawinan orang tuanya. Setelah menetapkan status adam wali nikah, selanjutnya KUA menetapkan bahwa wali nikah dilimpahkan kepada pejabat KUA di masing-masing wilayah yang terdapat di Kota Semarang. Adapun dasar yang dipakai oleh mereka yang menentukan yang melimpahkan wali nikah perempuan yang syarat walinya kurang kepada pihak KUA adalah karena mereka menggunakan dasar hukum yang terdapat di dalam penetapan adam wali nikah dalam Surat Dirjen Bimas dan Urusan Haji Nomor: D/ED/PW.01/03/1992 yang kedudukannya di bawah Undang-Undang Perkawinan Nomor 1 Tahun 1974 dan Kompilasi Hukum Islam (KHI).

Keywords: wali nikah; 'adam wali nikah; wali hakim 


\section{Pendahuluan}

Satu perkawinan dianggap sah, apabila perkawinan tersebut telah memenuhi syarat-syarat dan rukun-rukunnya. Salah satu masalah krusial dalam perkawinan yaitu, adanya "wali nikah" bagi calon mempelai perempuan. Keberadaan dan peran wali nikah sangat menentukan sah atau tidaknya sebuah perkawinan. Karena wali nikah menurut fikih dan Undang-Undang Nomor 1 Tahun 1974 tentang Perkawinan adalah termasuk rukun nikah, yang harus dipenuhi dalam sebuah perkawinan. Apabila perkawinan tanpa wali nikah, maka dianggap tidak sah perkawinannya.

Ketentuan wali nikah dalam Undang-Undang Nomor 1 Tahun 1974, banyak mengadopsi dari hukum Islam (fikih yang bermazhab Syafi'i) yang banyak dianut oleh orang Indonesia. Salah satu pendapatnya dalam masalah perkawinan bahwa kedudukan wali nikah merupakan salah satu rukun nikah, sehingga apabila seorang perempuan yang akan melakukan perkawinan disyaratkan harus ada walinya. Hal ini berarti bahwa perkawinan tanpa adanya wali, maka perkawinannya itu tidak sah.

Tidak ada pendapat ulama terdahulu mengenai 'adam wali. Namun di lapangan ditemukan beberapa pejabat KUA di Kota Semarang menetapkan istilah 'adam wali' bagi calon mempelai perempuan yang sudah mempunyai wali nikah. Dalam penilaian mereka wali nikah tersebut tidak atau belum memenuhi kriteria menjadi wali. Di antara sebab-sebab tersebut adalah tidak terpenuhinya seorang wali sebagai wali nikah, karena antara tanggal akad nikah orang tua dengan tanggal kelahiran anak pertama perempuannya yang akan menikah tidak terpenuhi batas minimal usia kandungan, yakni jarak enam (6) bulan dalam kandungan (masa kehamilan) ibunya, sehingga mereka (para pejabat KUA) yang nota bene hanya sebagai pencatat peristiwa terjadinya perkawinan, sangat berani menetapkan istilah 'adam wali dalam masalah tersebut.

Pernyataan atau penetapan istilah 'adam wali, dalam kajian fikih dan undang-undang perkawinan di Indonesia tidak ditemukan istilah tersebut, karena baik fikih maupun peraturan perundang-undangan dalam menyikapi masalah tersebut (batas minimal usia kandungan) sudah jelas. Menurut fikih atau hukum Islam, sebagaimana petunjuk al-Qur'an bahwa batas minimal usia 
bayi dalam kandungan adalah enam (6) bulan dihitung dari saat akad nikah dilangsungkan. Ketentuan tersebut diambil dari firman Allah QS. al-Aḥqāf: 15 dan QS. Luqmān: 14.

Kedua ayat tersebut menunjukkan bahwa tenggang waktu mengandung dan menyapihnya adalah 30 bulan. Sedangkan ayat yang kedua menerangkan bahwa menyapihnya setelah bayi disusukan secara sempurna membutuhkan waktu 2 tahun ( 24 bulan). Ini berarti bahwa, bayi membutuhkan waktu 30 - 24 bulan $=6$ bulan di dalam kandungan. Oleh karena itu, apabila bayi lahir kurang dari 6 bulan, maka tidak bisa dihubungkan kekerabatannya (nasabnya) kepada bapaknya, meskipun bayi tersebut lahir dalam ikatan perkawinan yang sah. Ini berarti bahwa bayi atau anak tersebut dianggap sebagai bayi atau anak yang lahir diluar perkawinan, sehingga ia hanya mempunyai hubungan nasab dengan ibunya dan keluarga ibunya.

Dengan kata lain, orang tuanya (bapak) tidak bisa menjadi wali nikah menurut ketentuan hukum Islam (fikih), maka kewenangan hak perwaliannya pindah menjadi "wali hakim", bukan dengan istilah 'adam wali. Hal ini berbeda jauh dengan ketentuan yang ada dalam undang-undang perkawinan dan dikuatkan dengan Kompilasi Hukum Islam (KHI). Dalam Pasal 42 UndangUndang Perkawinan dinyatakan bahwa:

"Anak yang sah adalah anak yang dilahirkan dalam atau sebagai akibat perkawinan yang sah".

Selanjutnya Pasal 43 yang dinyatakan bahwa:

"Anak yang dilahirkan di luar perkawinan hanya mempunyai hubungan perdata dengan ibunya dan keluarga ibunya".

Sementara KHI menguatkan kembali pernyataan tersebut dalam Pasal 99 yang menyebut bahwa;

"Anak yang sah adalah a) anak yang dilahirkan dalam atau akibat perkawinan yang sah., b) hasil pembuahan suami-istri yang sah di luar rahim dan dilahirkan oleh istri tersebut. Selanjutnya Pasal 100 dinyatakan bahwa "Anak yang lahir di luar perkawinan hanya mempunyai hubungan nasab dengan ibunya dan keluarga ibunya".

Dari ketentuan tersebut bisa diketahui siapa yang berhak menjadi wali nikah dari anak perempuan yang akan menikah. Mengenai ketentuan wali nikah dalam KHI Pasal 20: 
Rokhmadi

(l) Yang bertindak sebagai wali nikah ialah seorang laki-laki yang memenuhi syarat hukum Islam, yakni muslim, aqil dan baligh.

(2) Wali nikah terdiri dari: a) wali nasab, dan b) wali hakim.

Kemudian mengenai perpindahan wali nasab ke wali hakim, dalam Pasal 23:

(l) Wali hakim baru dapat bertindak sebagai wali nikah, apabila wali nasab tidak ada atau tidak mungkin menghadirkannya atau tidak diketahui tempat tinggalnya atau ghaib atau adlal atau enggan".

Tulisan ini akan mengelaborasi lebih lanjut penetapan pejabat KUA di Kota Semarang tentang status 'adam wali nikah bagi calon mempelai dan landasan hukum yang dijadikan acuan oleh para pejabat KUA tersebut.

\section{Kedudukan dan Dasar Wali dalam Perkawinan}

Secara etimologi "wali" mempunyai arti pelindung, penolong, atau penguasa. ${ }^{1}$ Wali mempunyai banyak arti, antara lain; orang yang menurut hukum (agama dan adat) diserahi kewajiban mengurus anak yatim serta hartanya sebelum anak itu dewasa. Juga bisa berarti pengasuh pengantin perempuan pada waktu menikah yaitu yang melakukan janji nikah dengan pengantin lakilaki. Atau lebih singkat berarti orang shaleh (suci), penyebar agama, atau kepala pemerintahan dan sebagainya. $^{2}$

Beberapa arti "wali" di atas tentu saja pemakaiannya dapat disesuaikan dengan konteks kalimat. Adapun yang dimaksud wali dalam pembahasan ini adalah wali dalam pernikahan. Orang yang berhak menikahkan seorang perempuan adalah orang tua laki-laki (bapak) perempuan tersebut dan orangorang secara fikih berhak menjadi wali. Menurut jumhur ulama mengatakan bahwa wali adalah ahli waris laki-laki dari keturunan ayah, bukan dari keturunan ibu.

Adapun pengertian wali menurut terminologi adalah kewenangan yang diberikan kepada seseorang untuk melakukan sesuatu perbuatan hukum

1H.M.A. Tihami, dan Sohari Sharani, Fikih Munakahat, Kajian Fikih Nikah Lengkap (Jakarta: Raja Grafindo Persada, 2009), h. 89.

2Ibid. 
sebagai wakil untuk kepentingan dan atas nama anak. Atau dengan kata lain wali adalah seseorang yang karena kedudukannya berwenang untuk bertindak terhadap dan atas nama orang lain. ${ }^{3}$ Dalam perkawinan wali itu adalah seseorang yang bertindak atas nama mempelai perempuan dalam suatu akad nikah. Akad nikah dilakukan oleh dua pihak, yaitu pihak perempuan yang dilakukan oleh walinya dan pihak mempelai laki-laki itu sendiri. Berkaitan dengan wali nikah adalah orang yang mempunyai hubungan nasab dengan anak perempuan yang mau menikah.

Keberadaan seorang wali dalam akad nikah adalah suatu yang pasti dan tidak sah akad perkawinan seseorang perempuan yang tidak dilakukan oleh wali. Wali itu ditempatkan sebagai salah satu rukun nikah menurut kesepakatan jumhur ulama. ${ }^{4}$ Dalam akad perkawinan itu sendiri wali dapat berdudukan sebagai orang yang bertindak atas nama mempelai perempuan dan dapat pula sebagai orang yang diminta persetujuannya untuk kelangsungan perkawinan tersebut.

Dalam mendudukkan wali sebagai orang yang bertindak atas nama mempelai perempuan dalam melakukan akad nikah terdapat beda pendapat di antara para fuqaha'/ulama. Berkaitan dengan mempelai yang masih kecil (belum baligh) ulama sepakat, bahwa wali kedudukannya sebagai rukun atau syarat akad perkawinan. Alasannya ialah mempelai yang masih kecil tidak dapat melakukan akad untuk dirinya sendiri, maka akad tersebut dilakukan oleh walinya. Namun terhadap perempuan dewasa baik ia sudah janda atau masih perawan, ulama berbeda pendapat. Beda pendapat tersebut oleh karena tidak adanya dalil yang pasti ( $q a t^{\prime} i y$ ) yang dapat dijadikan rujukan hukum.

Beberapa ayat al-Qur'an yang mengisyaratkan keberadaan wali nikah antara lain QS. al-Nūr: 32; QS. al-Baqarah: 221; QS. al-Baqarah: 232, 234. 'Ibarat naș keempat ayat tersebut tidak menunjukkan keharusan adanya wali, karena ayat yang pertama adanya perintah untuk menikahkan orang-orang yang masih

\footnotetext{
${ }^{3}$ Amir Syarifuddin, Hukum Perkawinan Islam di Indonesia, antara Fiqh dan Undang-Undang Perkawinan (Jakarta: Kencana, 2007), h. 69.

${ }^{4}$ Abd al-Raḥmān al-Jaziriy, Kitāb al-Fiqh 'alā 7-Madhāhib al-Arba'ah, Juz IV (t.t...: Dār al-Taqwā lilțaba' wa al-Nasyr wa al-Tawzi',t.th.), h. 12.
} 
perawan atau bujang, ayat yang kedua larangan perkawinan antara perempuan muslimah dengan laki-laki musyrik, ayat ketiga dan keempat larangan menghalangi perempuan yang habis masa iddahnya untuk nikah lagi. Namun karena dalam keempat ayat itu khitab Allah berkenaan dengan perkawinan yang dialamatkan kepada wali, maka dapat pula dipahami keharusan adanya wali dalam perkawinan. Dari pemahaman keempat ayat tersebut di atas, maka jumhur ulama menetapkan keharusan adanya wali dalam perkawinan, sehingga kedudukan wali menjadi salah satu rukun atau syarat sahnya perkawinan. ${ }^{5}$

Disamping itu, terdapat pula kedudukan dan dasar-dasar ayat al-Qur'an yang tidak mengisyaratkan wali nikah, yang memberikan pengertian perempuan itu boleh nikah tanpa memakai wali, di antaranya QS. al-Baqarah: 230, 232, 234.

QS. al-Baqarah: 232 menyatakan bahwa perempuan itu menikahi bekas suaminya dan wali dilarang itu mencegahnya. QS. al-Baqarah: 234 menyatakan bahwa perempuan itu berbuat (nikah) atas dirinya sendiri, dan QS. al-Baqarah: 230 dengan jelas menyatakan bahwa perempuan itu melakukan perkawinan dengan laki-laki lain. Dari ketiga ayat tersebut fā'il atau pelaku dari perkawinan itu adalah perempuan itu sendiri tanpa disebutkan adanya wali.

Berdasarkan dari dasar ayat-ayat al-Qur'an kelompok kedua tersebut di atas mengenai kedukukan wali dalam perkawinan, maka ulama Hanafiyyah dan Syi'ah Imamiyyah berkesimpulan bahwa perempuan yang sudah dewasa dan sehat akalnya dapat melakukan sendiri perkawinannya dan tidak perlu wali untuk mengakadkannya. ${ }^{6}$ Alasan rasionalnya ialah orang yang sudah dewasa dan sehat akalnya dapat bertindak hukum dengan sendirinya tanpa diperlukan bantuan walinya, termasuk juga dalam perkawinannya.

Jumhur ulama yaitu Maliki, Syafi'i, dan Hanbali disamping menggunakan ayat-ayat pertama di atas sebagai dalil yang mewajibkan wali dalam perkawinan, menguatkan pendapatnya itu dengan serangkaian hadis-hadis, seperti hadis dari Abū Mūsā yang menyebutkan bahwa Rasulullah bersabda: "Tidak sah nikah tanpa wali dan dua orang saksi". (HR. Aḥmad, Abū Dāwūd, Tïrmidhi,

${ }^{5} \mathrm{Abd}$ al-Rahman al-Jaziriy, Kitāb al-Fiqh 'ala 7-Madhāhib al-Arba'ah, Juz IV, h. 12.

${ }^{6} I$ bid., h. 13. Lihat juga Amir Syarifuddin, Hukum Perkawinan Islam di Indonesia, h. 72. 
Ibn Hibban dan Hakim dan disahkan oleh keduanya). ${ }^{7}$ Juga hadis dari 'Aisyah yang menyatakan, sesungguhnya Rasulullah bersabda: "Siapapun di antara wanita yang menikah tanpa seizin walinya, maka nikahnya batal, nikahnya batal, nikahnya batal. Jika laki-lakinya telah menyetubuhinya, maka ia berhak atas maharnya, karena ia telah menghalalkan kehormatannya (farji-nya). Jika pihak wali enggan untuk menikahkannya, maka hakimlah yang berhak menjadi wali bagi seseorang perempuan yang tidak ada walinya". Hadis lainnya dari Abi Hurairah bahwasannya Nabi bersabda: "Janganlah (tidak boleh) perempuan menikahkan perempuan dan perempuan juga tidak boleh menikahkan dirinya sendiri, yang demikain itu adalah berzina".8

Sedangkan golongan Hanafiyyah dan Syi'ah Imamiyyah yang tidak mewajibkan adanya wali nikah bagi perempuan dewasa dan sehat akalnya, menanggapi hadis-hadis pertama di atas dengan menyatakan bahwa hadis tersebut mengandung dua arti; Pertama, tidak sempurna suatu perkawinan tanpa adanya wali, ini berarti perkawinannya tidak sah, tapi kurang sempurna, dan kedua, jika kata 'tidak' itu diartikan dengan tidak sah, maka arahnya adalah kepada perempuan yang masih kecil (belum dewasa) atau tidak sehat akalnya, karena terhadap dua perempuan tersebut ulama Hanafiyyah, sebagaimana ulama Jumhur juga mewajibkan adanya wali.

Sedangkan untuk hadis yang kedua ulama Hanafiyyah dan pengikutnya mengatakan bahwa perkawinan yang batal itu adalah jika perkawinan yang dilakukan tanpa izin dari wali, bukan yang menikahkan harus wali. Kemudian hadis ketiga yang melarang perempuan menikahkan dirinya atau perempuan lain itu adalah jika perempuan itu masih kecil, sedangkan yang sudah dewasa boleh saja ia menikahkan dirinya atau orang lain, apalagi jika perempuan tersebut dewasa dan sudah janda.

Disamping pembelaan Hanafiyyah terhadap hadis-hadis yang dikemukakan oleh jumhur ulama, ulama Hanafiyyah juga mengemukakan beberapa

${ }^{7}$ Sayyid Sabiq, Fiqh Sunnah, (terj) .jilid 7 (Bandung: Al-Ma'arif, 1997), h. 12. Lihat juga al-Imām Taqiy al-Dīn Abī Bakr ibn Muhammad al-Husayniy, Kafāyah al-Akhyār, Juz II (Surabaya: Muhammad ibn Ahmad ibn Nabhạn wa Awladih. t.th.), h. 48.

8al-Imam Taqiy al-Din Abi Bakr bin Muhammad al-Husayniy, ibid. 
hadis yang dapat mendukung pendapatnya. Di antaranya hadis dari Ibnu 'Abbas ra, bahwasannya Rasulullah bersabda: "Janda lebih berhak kepada dirinya sendiri daripada walinya, dan gadis hendaknya diminta idzinnya dalam perkara dirinya, dan idzinnya adalah diamnya". (HR. Jama'ah kecuali Bukhari) ${ }^{9}$. Juga Hadis Abi Hurairah, bahwasannya Rasulullah bersabda: "Janda tidak boleh dinikahkan sebelum diajak berunding, dan gadis sebelum dimintai persetujuannya". Mereka bertanya: Wahai, Rasulullah: bagaimana izinnya? Jawabnya: "Diamnya".10

Mereka juga menyebut riwayat Abū Dāwūd, dan al-Nasā'i yang menyatakan peristiwa Khansa binti Khidam. Khansa menyampaikan bahwa dirinya dinikahkan oleh ayahnya setelah ia janda, maka ia menghadap Rasulullah mengadukan perkaranya, maka Rasulullah membatalkan pernikahannya."11 Riwayat yang satu lagi diceritakan oleh Ibnu 'Abbas bahwa Rasulullah, bersabda: "Tidak ada kekuasaan bagi wali terhadap perempuan yang sudah janda."12

Dua kubu yang berbeda secara prinsip tersebut di atas dapat dijelaskan sebagai berikut: menurut ulama Hanafiyyah dan Syi'ah Imamiyyah berpendapat bahwa untuk perkawinan anak kecil baik sehat akal maupun tidak diwajibkan adanya wali yang akan mengakadkan perkawinannya. Sedangkan bagi perempuan yang sudah dewasa apalagi sudah janda dan sehat akalnya dapat melangsungkan sendiri akad perkawinannya tanpa ada wali.

Sedangkan dalam pandangan ulama Syafi'iyyah dan Hanabilah berpendapat bahwa setiap akad perkawinan harus dilakukan oleh walinya, baik perempuan itu dewasa atau masih kecil, janda atau gadis, sehat akalnya atau tidak. Tidak ada hak sama sekali bagi perempuan untuk mengakadkan perkawinannya.

Ulama Zhahiriyyah juga berpendapat bahwa untuk perempuan yang masih kecil atau tidak sehat akalnya diwajibkan adanya wali, sedangkan untuk per-

\footnotetext{
${ }^{9}$ Sayyid Sabiq, Fiqh Sunnah, jilid 7, h. 18.

${ }^{10}$ Ibid.

${ }^{11} \mathrm{HR}$. Jama'ah kecuali Muslim, ibid, h. 19.

${ }^{12}$ HR. Abū Dāwūd dan al-Nasā'i yang disahkan oleh Ibn Hibban. Amir Syarifuddin, Hukum Perkawinan Islam di Indonesia, h. 73.
} 
empuan yang sudah dewasa yang diwajibkan adalah izin wali untuk melangsungkan perkawinan, bukan untuk diakadkan wali, karena jika yang mengakadkannya adalah walinya, maka tentu tidak diperlukan lagi adanya izin walinya. ${ }^{13}$

Berbeda dengan dua pendapat di atas, menurut pendapat Imam Malik, menurut riwayat Asyhab, wali merupakan hal mutlak dalam suatu perkawinan dan tidak sah perkawinannya tanpa adanya wali. Namun menurut riwayat Ibnu Qasim, keberadaan wali hanyalah sunnah hukumnya dan tidak wajib.

\section{Pendapat Pejabat KUA di Kota Semarang tentang Penetapan Status Hukum 'Adam Wali Nikah}

Penentuan 'adam wali nikah dalam pandangan Muadhim, kepala KUA Banyumanik, diketahui dengan cara meneliti berkas/data dari calon mempelai perempuan dan data orang yang akan menjadi wali dari calon mempelai perempuan tersebut. Ketentuannya jarak antara tanggal kelahiran anak perempuannya dengan akad nikah wali/bapak (orang tunya) kurang dari 6 bulan usia kandungan menurut fikih, dan berdasarkan Surat Dirjen Bimas dan Urusan Haji No. D/ED/PW.01/03/1992 tentang 'Adam Wali Nikah.

Disamping itu, Muadhim beralasan bahwa wali nasab pindah menjadi wali hakim jika dalam keadaan hal-hal sebagai berikut; Sudah tidak ada lagi garis wali nasab; walinya mafqūd (hilang); walinya sendiri yang mau menikahi perempuan itu yang tidak sederajat; walinya ba'îd/masafah al-qashri $\pm 92,5$ $\mathrm{km}$.; walinya sakit (gila, ayam, pitam); walinya tidak boleh dihubungi (dipenjara); walinya dicabut haknya oleh negara; walinya ihram; walinya bersembunyi/ tawarra'; walinya uzur; dan walinya adlal.14

Muadhim juga masih mengakui masih adanya nikah sirri menurut pengakuan mereka dengan bukti para saksi-saksi dan pemuka agama setempat. Bagi yang belum melakukan nikah sirri, untuk menghindari rasa malu/aib orang tua mempelai terhadap masyarakat, maka beliau menyarankan kepada

\footnotetext{
13Ibid, h. 74-75.

${ }^{14}$ Berdasarkan pada Peraturan Menteri Agama Republik Indonesia No. 2 Tahun 1987 tentang
} Wali Hakim. 
orang tua (wali yang sudah hilang hak kewaliannya) untuk mewakilkan peran wali kepada KUA (taukil). ${ }^{15}$

Pendapat yang hampir sama juga dikemukakan Sugiri, kepala KUA Kecamatan Ngaliyan, yang juga meneliti berkas/data dari calon mempelai perempuan dengan data yang akan menjadi wali dari calon mempelai perempuan. Ketentuannya juga sama, yaitu jarak antara tanggal kelahiran anak perempuannya dengan akad nikah wali/bapak (orang tunya) kurang dari 6 bulan usia kandungan menurut fikih. sebagaimana Surat Dirjen Bimas dan Urusan Haji No. D/ED/PW.01/03/1992 tentang 'Adam Wali Nikah dengan rumus jika H -6, maksudnya kelahiran mempelai perempuan kurang dari 6 bulan usia kandungan dengan akad nikah orang tunya, maka status hukumnya adalah 'adam wali, akan tetapi jika masih $\mathrm{H}+1$, maksudnya kelahiran mempelai perempuan sudah di atas 6 bulan usia kandungan, maka status hukumnya adalah wali nasab. Hal tersebut bisa diketahui berdasarkan dari data yang tertulis dalam akte nikah orang tua dengan akta lahir mempelai perempuan.

Sugiri selaku kepala KUA tidak mengakui akad nikah berlaku surut, maksudnya jika ada orang yang mau menikah di KUA sedangkan menurut pengakuan mereka sudah melakukan akad nikah sendiri menurut agamanya masingmasing, maka pembuatan tanggal akta nikahpun tetap sesuai dengan tanggal mereka melakukan akad nikah di KUA setempat, tanpa memperhatikan pengakuan mereka yang telah menikah sesuai dengan ketentuan agama (nikah sirri), meskipun mereka membawa saksi-saksi. Hal ini dikarenakan ia tidak mengakui adanya nikah sirri, sebagaimana pernyataan mereka dan kebanyakan masyarakat pada umumnya.16 Sugiri juga menjelaskan tentang alasan-alasan wali nasab pindah menjadi wali hakim.

Langkah yang sama juga diambil Duta Grafika, kepala KUA Kecamatan Gajah Mungkur dalam menetapkan 'adam wali nikah. Ia meneliti berkas/data dari calon mempelai perempuan dengan data yang akan menjadi wali dari calon mempelai perempuan tersebut. Apabila calon mempelai itu anak

\footnotetext{
${ }^{15}$ Hasil wawancara dan observasi langsung di KUA Kecamatan Banyumanik Jln. Grafika No. 2 BanyumanikSemarang dengan H. Muadhim, S.Ag, Kepala KUA Banyumanik, pada tanggal 27 Juli 2011.

${ }^{16}$ Hasil wawancara dan observasi langsung di KUA Kecamatan Ngaliyan, Jln. Prof. Dr. Hamka No. 34 Ngaliyan Semarang dengan Drs. Sugiri, M.M., Wakil Kepala KUA Ngaliyan, pada tanggal 19 Juli 2011.
} 
pertama dan walinya wali, perlu dipertanyakan tanggal kelahiran anak perempuan pertamanya dengan akad nikah wali/bapak (orang tunya), bila terdapat ketidakwajaran, seperti baru lima bulan nikah, anak pertama lahir, maka anak tersebut masuk kategori anak ibunya, dengan demikian perlu diambil jalan tạ̣kim (wali hakim). ${ }^{17}$

Akan tetapi Grafika masih melakukan opsi/penawaran kepada para wali untuk menentukan sikap apakah status wali menurut fikih (agama Islam) atau menurut Undang-undang Perkawinan dan Kompilasi Hukum Islam. Sepengetahuannya status wali menurut fikih yang berhak menikahkan anak perempuanya adalah apabila jarak antara tanggal kelahiran anak perempuannya dengan akad nikah wali/bapak (orang tunya) lebih dari 6 bulan usia kandungan. Jika belahiran anak perempuan pertamanya kurang dari 6 bulan, maka bapaknya tidak berhak menjadi wali, atau dengan istilah 'adam wali, sehingga hak perwaliannya pindah ke wali hakim. Sedangkan, status ketentuan wali menurut UU Perkawinan Pasal 42 menyatakan bahwa:

"Anak yang sah adalah anak yang dilahirkan dalam atau sebagai akibat perkawinan yang sah."

Kemudian Pasal 43 menyatakan;

(1) Anak yang dilahirkan di luar perkawinan hanya mempunyai hubungan perdata dengan ibunya dan keluarga ibunya;

(2) Kedudukan anak tersebut ayat (1) di atas selanjutnya akan diatur dalam Peraturan Pemerintah.

Berdasarkan Undang-undang Perkawinan tersebut, untuk menentukan status wali nikah adalah mudah yaitu jika anak itu lahir setelah orang tuanya akad nikah, maka orang tua (bapaknya) sudah berhak menjadi wali nikah, meskipun jarak antara akad nikah orang tua dengan kelahiran anaknya kurang dari 6 bulan. Kemudian untuk menentukan ketentuan wali nikah dalam Kompilasi Hukum Islam juga ditegaskan dan dirinci sesuai apa yang telah diatur dalam UU Perkawinan, yaitu dalam Pasal 99 menyatakan bahwa:

\footnotetext{
${ }^{17}$ Surat Dirjen Bimas dan Urusan Haji No. D/ED/PW.01/03/1992 tentang Adam Wali Nikah, Bab III Hurmatul Mushaharah.
} 
Rokhmadi

"Anak yang sah adalah; a) anak yang dilahirkan dalam atau sebagai akibat perkawinan yang sah; b) hasil pembuahan suami-istri yang sah di luar rahim dan dilahirkan oleh istri tersebut.

Sedangkan Pasal 100 menyatakan bahwa:

"Anak yang lahir di luar perkawinan hanya mempunyai hubungan nasab dengan ibunya dan keluarga ibunya."

Dengan demikian, ketentuan wali nikah dalam Kompilasi Hukum Islam adalah sama dengan ketentuan dalam Undang-Undang Perkawinan No. 1 Tahun 1974, yaitu orang tua (bapaknya) sudah berhak menjadi wali nikah, meskipun jarak antara akad nikah orang tua dengan kelahiran anaknya kurang dari 6 bulan.

Pengambilan kebijaksanaan tersebut tetap menghargai keyakinan masyarakat yang masih menganggap adanya nikah sirri, yaitu nikah yang telah terpenuhi syarat dan rukun nikah menurut fikih, tetapi belum dicacatkan dalam akte nikah yang dibuat oleh pejabat KUA. Akan tetapi menurutnya sebagai pejabat KUA tidak ada istilah nikah sirri, karena masalah perkawinan sudah masuk wilayah negara (hukum Positif), sehingga nikah yang sah adalah nikah yang dilakukan menurut ketentuan negara. Jadi, yang dimaksud menurut agamanya adalah agama yang diakui dan dilindungi oleh pemerintah, bukan menurut fikih yang masih relatif kebenarannya. ${ }^{18}$

Kepala KUA lainnya, Sinwani, Kepala KUA Kecamatan Candisari, juga menyebutkan bahwa untuk menentukan status hukum "adam wali nikah" dengan cara meneliti berkas/data dari calon mempelai perempuan dengan data yang akan menjadi wali dari calon mempelai perempuan tersebut, yaitu jika calon mempelai itu anak pertama dan walinya wali, perlu dipertanyakan tanggal kelahiran anak perempuan pertamanya dengan akad nikah wali/ bapak (orang tunya), bila terdapat ketidakwajaran, seperti baru lima bulan nikah, anak pertama lahir, maka anak tersbut masuk kategori anak ibunya, dengan demikian perlu diambil jalan tahkìm (wali hakim). ${ }^{19}$

\footnotetext{
${ }^{18}$ Hasil wawancara dan observasi langsung di KUA Kecamatan Gajah Mungkur, Jln. Kelud Selatan II/26 Semarang dengan Duta Grafika, S.Ag, Kepala KUA Gajah Mungkur, pada tanggal 27 Juli 2011.

${ }^{19}$ Surat Dirjen Bimas dan Urusan Haji No. D/ED/PW.01/03/1992. tentang Adam Wali Nikah.
} 
Berkenaan dengan nikah sirri, Sinwani masih mengakui/mengesahkan pernikahan menurut fikih (agamanya) selama dalam melangsungkan pernikahannya sudah terpenuhi syarat dan rukun nikah, yaitu adanya wali nasab, mempelai perempuan, mempelai laki-laki, 2 orang saksi dan ijab qabul (akad nikah), dan mempunyai bukti dan saksi-saksi yang dapat dipertanggungjawabkan baik menurut agama maupun menurut hukum negara. Oleh karena itu, untuk menentukan status hukum wali nikah masih memberikan toleransi keyakinan atau pendapat tokoh masyarakat setempat, selama mereka benarbenar melaksanakannya sesuai dengan keyakinan agamanya, tidak direkayasa seolah-olah perkawinannya sudah menurut agamanya. Ia mencontohkan, tidak menggunakan wali yang tidak berhak menjadi wali, karena wali nasabnya tidak menyetujui kemudian mencari wali lain yang tidak ada hak kewaliannya atau mereka hanya mengaku-ngaku sudah nikah sirri. Maka untuk menentukan hal tersebut, ia menyuruh mendatangkan bukti dan para saksi untuk disumpah, bahwa mereka sudah benar-benar melakukan pernikahan menurut keyakinan agamanya (nikah sirri). ${ }^{20}$

\section{Istinbāt Hukum Pejabat KUA di Kota Semarang dalam Menetapkan Status Hukum 'Adam Wali Nikah}

Dari wawancara yang penulis lakukan, diketahui bahwa istinbāt hukum yang dipakai adalah sebagai berikut; pertama, dengan mendasarkan firman Allah QS. al-Ahqāâ: 15 dan QS: Luqmān: 14. Kedua ayat tersebut menurut lbnu Abbas dan disepakati para ulama, ditafsirkan bahwa ayat pertama menunjukkan bahwa tenggang waktu mengandung dan menyapihnya adalah 30 bulan. Sedangkan ayat kedua menerangkan bahwa menyapihnya setelah bayi disusukan secara sempurna membutuhkan waktu 2 tahun ( 24 bulan). Ini berarti bahwa, bayi membutuhkan waktu $30-24$ bulan $=6$ bulan di dalam kandungan. Oleh karena itu, apabila bayi lahir kurang dari 6 bulan, maka tidak bisa dihubungkan kekerabatannya (nasabnya) kepada bapaknya, meskipun bayi tersebut lahir dalam ikatan perkawinan yang sah. Ini berarti bahwa bayi

\footnotetext{
${ }^{20}$ Hasil wawancara dan observasi langsung di KUA Kecamatan Candisari Jln. Taman Teuku Umar No. 2 Semarang dengan Drs. H. Sinwani, Kepala KUA Candisari, pada tanggal 27 Juli 2011.
} 
atau anak tersebut dianggap sebagai bayi atau anak yang lahir di luar perkawinan, sehingga ia hanya mempunyai hubungan nasab dengan ibunya dan keluarga ibunya. Dengan kata lain, orang tuanya (bapaknya) tidak bisa menjadi wali nikah menurut ketentuan hukum Islam (fikih), maka kewenangan hak perwaliannya pindah menjadi "wali hakim".21

Kedua, dengan memperhatikan Surat Dirjen Bimas dan Urusan Haji No. D/ED/PW.01/03/1992, tentang 'Adam Wali Nikah, yang menyatakan bahwa apabila calon mempelai wanita itu anak pertama dan walinya wali ayah, perlu ditanyakan tanggal nikah dan tanggal lahir anak pertamanya itu, bila terdapat ketidakwajaran, seperti baru lima bulan nikah, anak pertama lahir, maka anak tersebut masuk kategori anak ibunya, dengan demikian perlu diambil jalan tahkim (wali hakim). Hal ini berdasarkan pada al-Muhadhdhab juz II yang menyatakan: "Anak yang lahir jika nasabnya dapat dihubungkan kepada lelaki yang menikahi dan (berdasarkan fakta) tidak dapat dipisahkan, maka jika anak tersebut lahir enam bulan setelah akad nikah dihitung anak sah bagi lelaki yang menikahi ibunya. Jika anak itu lahir kurang enam bulan dari akad nikah, maka anak tersebut bukan anak orang lelaki yang menikahi ibunya."22 Pernyataan tersebut ternyata mendasarkan pada hadis dari Abū Hurairah yang menceritakan bahwa sesungguhnya Nabi bersabda: "Anak itu kepunyaan firāsh (ibunya/yang menjadi seprei), sedang laki-laki yang berzina mendapatkan hukum batu (dirajam). ${ }^{23}$

Anak perempuan pertama yang lahir kurang enam bulan dari akad nikah orang tuanya, nasabnya dihubungkan kepada ibunya, maka ayahnya tidak berhak menjadi wali, karena tidak mempunyai wali, sehingga disebut 'adam wali. Karena statusnya 'adam wali (tidak mempunyai wali), maka wali yang berhak menjadi wali nikahnya adalah wali hakim. Hal ini berdasarkan hadis dari 'Aisyah yang menerangkan bahwa hakimlah yang berhak menjadi wali bagi seseorang perempuan yang tidak ada walinya. ${ }^{24}$

\footnotetext{
${ }^{21} \mathrm{Ahmad}$ Rofiq, Hukum Islam di Indonesia (Jakarta: Raja Grafindo Persada, 2000), h. 223-224.

${ }^{22} \mathrm{Abū}$ Isḥ̄ā Ibrāhīm ibn 'Ali ibn Yūsuf al-Fayruzabadiy al-Shayrazī, al-Muhadhdhab, Juz II, t.t.p.: Dar al-Fikr, t.th., h. 130.

23al-Shan'aniy, Subul al-Salām, Juz III (Kairo: Dār Ihỵā' al-Turāth al-'Arabiy, 1960), h. 124.

${ }^{24}$ al-Tirmidhi, Sunan al-Tirmidhi, Juz III (Beirut-Libanon: Dar al-Kutub al-'Ilmiyyah, t.th.), h. 400. Lihat juga Abū Dāwūd, Sunan Abā Dāwūd, Juz III (Beirut: Dār al-Kutub al-'Ilmiyyah, tth.), h. 305.
} 


\section{Analisis Pendapat Pejabat KUA yang Berdasarkan Surat Dirjen Bimas dan Urusan Haji No. D/ED/PW.01/03/1992 tentang Ketentuan 'Adam Wali Nikah}

Jika pendapat tersebut di atas dianalisis khususnya menetapkan 'adam wali nikah, memang sesungguhnya semua pejabat KUA tidak bersalah karena memang sudah ada pedomannya dari Surat Dirjen Bimas dan Urusan Haji No. D/ED/PW.01/03/1992 tentang Ketentuan 'Adam Wali, mereka hanya melaksanakan tugas sesuai dengan perintah atasannya. Akan tetapi, jika dilihat dari kekuatan hukumnya untuk dasar menentukan 'adam wali nikah hanya atas dasar Surat Dirjen Bimas dan Urusan Haji No. D/ED/PW.01/03/1992 tidak benar atau tidak wajib dipatuhi Surat Dirjen tersebut, karena hal itu bertentangan dengan ketentuan yang sudah ada dalam status ketentuan wali menurut Undang-Undang No. 1 Tahun 1974 tentang Perkawinan, Pasal 42 dan Pasal 43. Pasal 42 menyatakan bahwa anak yang sah adalah anak yang dilahirkan dalam atau sebagai akibat perkawinan yang sah. Kemudian Pasal 43 menyatakan; 1) Anak yang dilahirkan di luar perkawinan hanya mempunyai hubungan perdata dengan ibunya dan keluarga ibunya; 2) Kedudukan anak tersebut ayat (1) di atas selanjutnya akan diatur dalam Peraturan Pemerintah. Jika berdasarkan Undang-Undang Perkawinan tersebut, maka untuk menentukan status wali nikah adalah mudah yaitu jika anak itu lahir setelah orang tuanya akad nikah, maka orang tua (bapaknya) sudah berhak menjadi wali nikah, meskipun jarak antara akad nikah orang tua dengan kelahiran anaknya kurang dari 6 bulan.

Kemudian ketentuan mengenai anak sah kaitannya dengan ketentuan wali tersebut juga dikuatkan dengan terbitnya Kompilasi Hukum Islam yang menjelaskan dan dirinci sesuai apa yang telah diatur dalam Undang-Undang Perkawinan, yaitu dalam Pasal 99 menyatakan bahwa: "Anak yang sah adalah; a) Anak yang dilahirkan dalam atau sebagai akibat perkawinan yang sah; b) Hasil pembuahan suami-istri yang sah di luar rahim dan dilahirkan oleh istri tersebut." Sedangkan Pasal 100 menyatakan bahwa: "Anak yang lahir di luar perkawinan hanya mempunyai hubungan nasab dengan ibunya dan keluarga ibunya."

Dengan demikian, ketentuan wali nikah dalam Kompilasi Hukum Islam adalah sama dengan ketentuan dalam Undang-Undang Perkawinan, yaitu 
orang tua (bapaknya) sudah berhak menjadi wali nikah, meskipun jarak antara akad nikah orang tua dengan kelahiran anaknya kurang dari 6 bulan.

Pengambilan kebijaksanaan pemerintah (Undang-Undang Perkawinan) tersebut tetap menghargai keyakinan masyarakat yang masih menganggap adanya nikah sirri, yaitu nikah yang telah terpenuhi syarat dan rukun nikah menurut fikih, tetapi belum dicatatkan dalam akte nikah yang dibuat oleh pejabat KUA. Akan tetapi bagi mereka yang memang tidak pernah melaksanakan nikah (sirri), memang kebijaksanaan yang diambil oleh pejabat KUA berdasarkan Surat Dirjen tersebut adalah benar, karena memang mereka sebelumnya belum pernah menikah, sehingga bapaknya tidak berhak menjadi wali, maka hak perwaliannya pindah ke wali hakim. Hal ini tentunya tidak terlepas dari kaidah hukum Islam, yang sangat mendatangkan maslahat bagi tegaknya rumah tangga. Sejalan dengan prinsip "Menolak kemadlaratan lebih didahulukan daripada memperoleh kemaslahatan,"25 dan "Suatu tindakan/ kebijaksanaan (peraturan) pemerintah berdasarkan atas kepentingan dan kemaslahatan rakyatnya."26

Jika dilihat dari urutan kekuatan hukumnya, maka keberlakuan Undangundang Perkawinan dan Kompilasi Hukum Islam tentunya jauh lebih kuat dari keberlakuan Surat Dirjen Bimas dan Urusan Haji No. D/ED/PW.01/03/1992. Dengan kaidah hukum: lek generalis derogat lek specialis, artinya kekuatan hukum yang lebih umum (di atasnya) mengalahkan kekuatan hukum yang lebih khusus (di bawahnya).

Dengan kata lain keberlakuan Surat Dirjen tersebut masih eksis, khususnya bagi masyarakat yang melakukan kumpul kebo, sehingga para pejabat KUA tidak memperlakukan sama antara mereka yang sudah melakukan nikah sirri yang ada buktinya ${ }^{27}$ dengan mereka yang melakukan kumpul kebo. Tidak

\footnotetext{
${ }^{25}$ Mukhtar Yahya, dan Fatchurrahman, Dasar-dasar Pembinaan Hukum Fiqh Islami (Bandung: AlMa'arif 1986), h. 513.

${ }^{26}$ Ibid., h. 527.

27Untuk melakukan pembuktian, tidak hanya sekedar pengakuan mereka dan saksi-saksinya, tetapi perlu juga dibuktikan secara ilmiah dengan teknologi yang sudah canggih, yaitu dengan melakukan tes DNA (Deoxyribo Nucleic Acid). Yang dimaksud dengan DNA adalah suatu substansi
} 
hanya sekedar melihat dari data tanggal lahir mempelai perempuan dengan tanggal akad nikah orang tuanya, tetapi justru harus melakukan pengecekan tentang kebenaran pengakuan mereka yang telah nikah sirri sebelumnya. Setelah itu kemudian baru menentukan status hukumnya, apakah termasuk kategori 'adam wali ataukah tidak. Problem solving mestinya dikedepankan oleh para semua pejabat KUA, khususnya di Kota Semarang.

Secara epistemologi, hukum Islam Indonesia tidak menempatkan peraturan perundang-undangan itu sesuatu yang bertentangan dengan hukum Islam. Dengan pendekatan yang jernih dan rasional akan membuktikan bahwa peraturan pencatatan nikah itu tidak bertentangan dengan jiwa syari'ah Islam. Hal ini berdasarkan al-Qur'an surat al-Baqarah: 282.

Ada tiga pendekatan yang dapat dilakukan: pertama, pendekatan historis, menurut Ahmad Rofiq, itu boleh jadi karena pada masa kitab-kitab fikih ditulis, tingkat amanah umat Islam relatif sangat tinggi, sehingga kemungkinan untuk menyalahgunakan lembaga perkawinan untuk tujuan sesaat yang tidak sesuai dengan tujuan ideal perkawinan dan merugikan pihak itu, relatif kecil. Pernyataan ini bukan bermaksud menggeneralisir bahwa sekarang ini tingkat amanah masyarakat itu sudah luntur. ${ }^{28}$

ما لا ينم الواجب إلا به فهو واجب:Kedua, pendekatan qā'idah al-fiqhiyyah, yaitu Berkaitan dengan kaidah itu, maka pencatatan perkawinan merupakan peraturan yang sengaja dibuat untuk menyempurnakan kualitas sebuah lembaga perkawinan. Penyempurnaan tersebut merupakan bagian dari perintah Allah dalam rangka beribadah kepadaNya. Artinya, tiada sempurna sebuah per-

nucleus genetika dari tubuh manusia yang didapati hampir di seluruh sel tubuh manusia tersebut, yang dibawa lahir oleh manusia dan tidak pernah berubah, yang diambil dari bagian-bagian tubuh manusia, seperti; air liur, darah, semen (sperma), sel kulit, rambut, urine, keringat, dan lain-lain. Hal ini untuk menentukan hubungan darah (nasab) anak kepada orang tuanya. Macam-macam alat bukti dalam hukumacara pidana adalah terdiri dari keterangan saksi, keterangan ahli, surat, petunjuk, dan keterangan terdakwa, sedangkan alat bukti dalam hukum acara perdata sebagaimana yang ditentukan dalam pasal 164 HIR (Herzien Indonesisch Reglement), yaitu ; bukti tulisan, bukti saksi, bukti persangkaan, bukti pengakuan, dan bukti sumpah. Baca: Munir Fuady, Teori Hukum Pembuktian (Pidana dan Perdata) (Bandung: Citra Aditya Bakti, 2006), h. 171 dan 181.

${ }^{28}$ Ahmad Rofiq, Pembaharuan Hukum Islam di Indonesia (Yogyakarta: Gama Media, 2001), h. 107108. 
kawinan tanpa adanya pencatatan (akta nikah), maka adanya pencatatn perkawinan bisa menjadi wajib hukumnya demi sempurnanya ikatan perkawinan.

Ketiga, pendekatan mașlahat. Pendekatan ini muncul sebagai jawaban yang menyatakan bahwa perkawinan sirri atau tanpa akta nikah adalah sah menurut agama. Menurut hemat penulis, perkawinan sirri itu hanya sah menurut fikih, tapi belum sah menurut agama, karena agama Islam membawa pesan universal di bawah prinsip rahmat li al-'álamīn. Artinya, segala tindakan manusia hanya dapat dibenarkan dengan menggunakan justifikasi agama. Apalagi agama Islam, agama terbesar yang dianut bangsa Indonesia, diakui pemerintah, dan secara khusus pemerintah sudah mengakomodir dalam bentuk peraturan perundang-undangan, terutama lembaga perkawinan.

\section{Kesimpulan}

Dengan uraian di atas, dapat diambil kesimpulan bahwa pendapat dan istinbāt hukum yang digunakan oleh semua pejabat KUA di Kota Semarang mengenai penetapan status hukum "adam wali nikah", tidak semuanya tepat atau benar. Pertama, berkenaan dengan pendapat pejabat KUA di Kota Semarang yang menetapkan status 'adam wali nikah yang Surat Dirjen tersebut, tidak perlu dipahami dan ditaati secara letterlijk, apalagi jika dilihat dari urutan kekuatan hukumnya adalah keberlakuan Undang-Undang Perkawinan dan Kompilasi Hukum Islam, tentunya jauh lebih kuat dari keberlakuan Surat Dirjen Bimas dan Urusan Haji No. D/ED/PW.01/03/1992. Dengan kaidah hukum: lek generalis derogat lek specialis, artinya kekuatan hukum yang lebih umum (di atasnya) mengalahkan kekuatan hukum yang lebih khusus (di bawahnya). Dengan kata lain keberlakuan Surat Dirjen tersebut masih eksis, khususnya bagi masyarakat yang melakukan "kumpul kebo", sehingga para pejabat KUA tidak memperlakukan sama antara mereka yang sudah melakukan nikah sirri yang ada bukti kuat.

Kedua, berkenaan dengan istinbāt hukumnya adalah beberapa ayat QS. al-Baqarah: 233, QS. Luqmān: 14 dan QS. al-Ahqāf:15, beberapa hadis tersebut dan juga kitab al-Muhadhdhab, menurut hemat penulis bahwa batas minimal usia kehamilan 6 bulan adalah dihitung dari mereka akad nikah, baik akad nikah yang tercatat resmi di KUA (mempunyai akta nikah) maupun akad nikah yang tidak resmi (nikah sirri), tetapi tidak berlaku bagi mereka yang 
melakukan kumpul kebo/berzina, dan juga orang tuanya tidak melakukan akad nikah, sehingga. bayi atau anak tersebut dianggap sebagai bayi atau anak yang lahir diluar perkawinan, ia hanya mempunyai hubungan nasab dengan ibunya dan keluarga ibunya. Dengan kata lain, orang tuanya (bapaknya) tidak bisa menjadi wali nikah menurut ketentuan hukum Islam (fikih), maka kewenangan hak perwaliannya pindah menjadi "wali hakim". [a]

\section{DAFTAR PUSTAKA}

al-Bukhari, Șahīḥ al-Bukhārī, Juz III, Beirut: Dār al-Kutub al-'Ilmiyyah, 1412 $\mathrm{H} / 1992 \mathrm{M}$.

Dāwūd, Abū, Sunan Abū Dāwūd, Juz III, Beirut: Dār al-Kutub al-'Ilmiyyah, t.th.

Djamil, Fathurrahman, "Pengakuan Anak Luar Nikah dan Akibat Hukumnya", dalam buku Problematika Hukum Islam Kontemporer I, (ed) H. Chuzaimah T. Yanggo dan H.A. Hafiz Anshary A.Z, Jakarta: Pustaka Firdaus, 2008.

Fuady, Munir, Teori Hukum Pembuktian (Pidana dan Perdata), Bandung: Citra Aditya Bakti, 2006.

Ghofar EM, Abdul, Fikih Keluarga, Jakarta: Pustaka al-Kautsar, 2001.

Hadikusuma, Hilman, Hukum Perkawinan Indonesia, Bandung: Bandar Maju, 1990.

Hasil wawancara dan observasi langsung di KUA Kecamatan Banyumanik Jln. Grafika No. 2 Banyumanik Semarang dengan H. Muadhim, S.Ag, Kepala KUA Banyumanik, pada tanggal 27 Juli 2011.

Hasil wawancara dan observasi langsung di KUA Kecamatan Ngaliyan, Jln. Prof. Dr. Hamka No. 34 Ngaliyan Semarang dengan Drs. Sugiri, M.M., Wakil Kepala KUA Ngaliyan, pada tanggal 19 Juli 2011.

Hasil wawancara dan observasi langsung di KUA Kecamatan Gajah Mungkur, Jln. Kelud Selatan II/26 Semarang dengan Duta Grafika, S.Ag, Kepala KUA Gajah Mungkur, pada tanggal 27 Juli 2011.

Hasil wawancara dan observasi langsung di KUA Kecamatan Candisari, Jln. Taman Teuku Umar No. 2 Semarang dengan Drs. H. Sinwani, Kepala KUA Candisari, pada tanggal 27 Juli 2011.

al-Husayniy, al-Imām Taqiy al-Dīn Abī Bakr ibn Muhammad, t.th., Kifāyah alAkhyār, Juz II, Surabaya: Muhammad ibn Ahmad ibn Nabhān wa Awladih. 
Rokhmadi

Instruksi Presiden Nomor 1 Tahun 1991 tentang Kompilasi Hukum Islam.

al-Jaziriy, Abd al-Rahmān, Kitāb al-Fiqh 'ala I-Madhāhib al-Arba'ah, Juz IV, t.t.p.: Dar al-Taqwa lilṭhaba' wa 'l-Nasyr wa 'l-Tawzi', t.th.

Keputusan Menteri Agama Republik Indonesia No. 517 Tahun 2001 tentang Penataan Organisasi Kantor Urusan Agama Kecamatan.

Undang-Undang Nomr 1 Tahun 1974 tentang Perkawinan.

Peraturan Pemerintah No. 9 Tahun 1975 tentang Peraturan Pelaksana Undang-Undang Nomor 1 Tahun 1974.

Peraturan Menteri Agama No. 3 Tahun 2006. Dirjen Bimas Islam dan Penyelenggara Haji, dan sekarang dipisah menjadi dua, yaitu Dirjen Bimas Islam dan Dirjen Penyelenggara Haji dan Umrah.

Peraturan Menteri Agama Republik Indonesia No. 2 tahun 1987 tentang Wali Hakim.

Rofiq, Ahmad, Hukum Islam di Indonesia, Jakarta: Raja Grafindo Persada, 2000.

Pembaharuan Hukum Islam di Indonesia, Yogyakarta: Gama Media, 2001.

al-Shayrazī, Abū Ishāa Ibrāhīm ibn 'Ali ibn Yūsuf al-Fayruzabadiy, alMuhadhdhab, Juz II, t.t.p.: Dar al-Fikr, t.th.,

al-Shan'aniy, Subul al-Salām, Juz III, Kairo: Dār Ihyyā' al-Turāth al-'Arabiy, 1960.

Sabiq, Sayyid, Fiqh Sunnah (terj.), jilid 7, Bandung: al-Ma'arif, 1997.

Syarifuddin, Amir, Hukum Perkawinan Islam di Indonesia, antara Fiqh dan Undang-Undang Perkawinan, Jakarta: Kencana, 2007.

Syaukani, Imam (editor), Optimalisasi Peran KUA Melalui Jabatan Fungsional Penghulu, Jakarta: Puslitbang Kehidupan Keagamaan, 2007.

Surat Dirjen Bimas dan Urusan Haji No. D/ED/PW.01/03/1992 tentang 'Adam Wali Nikah, Bab III Hurmatul Mushaharah.

al-Tirmidhī, Sunan al-Tirmidhī, Juz III, Beirut: Dar al-Kutub al-'Ilmiyyah, t.th..

Tihami, H.M.A, dan Sohari Sharani, Fikih Munakahat, Kajian Fikih Nikah Lengkap, Jakarta: Raja Grafindo Persada, 2009.

Yahya, Mukhtar dan Fatchurrahman, Dasar-dasar Pembinaan Hukum Fiqh Islami, Bandung: Al-Ma'arif, 1986.

Zahrah, Muhammad Abū, al-Ahwāl al-Shakhsiyyah, t.t.p.: Dār al-Fikr al-Arabi, t.th.

222 || Volume 26, Nomor 2, Oktober 2016

AL-AHKAM

p-ISSN: 0854-4603; e-ISSN: 2502-3209 